\title{
PENGARUH PENAMBAHAN BITTERN PADA LIMBAH CAIR DARI PROSES PENCUCIAN INDUSTRI PENGOLAHAN IKAN
}

\author{
Dian Yanuarita $\mathrm{P}^{1}$, Shofiyya Julaika ${ }^{2}$, Abdul Malik ${ }^{3}$, Jose Londa Goa ${ }^{4}$ \\ Jurusan Teknik Kimia, Fakultas Teknologi Industri ${ }^{1,2,3,4}$ \\ Institut Teknologi Adhi Tama Surabaya \\ Email ${ }^{1}$ : dianyanuarita@gmail.com
}

\begin{abstract}
Waste water from washing processes in fish processing industry contains TSS, BOD and COD whose concentration exceed the limit standard. Accordingly, it needs to be first treated bore being disposed to the water drainages. This research was to indentify the effectineness of bittern reduce the content of TSS in waste water. Bittern contains magnesium, with high power ion that can be used as coagulant. The research was initiated by conditioning the waste water to reach $\mathrm{pH}$ 11. The bittern was added by 10, 20, 30 and 40\% of the waste water volume. Next, a jartest was exercised with stirring speed 100 rpm for 3 minutes. The best result was attained from 30-minute stirring with 40\% coagulant application, yielding TSS $80 \mathrm{mg} . \mathrm{L}^{-1}$, BOD 48,63 mg.L $\mathrm{L}^{-1}$ and COD $93.50 \mathrm{mg} . \mathrm{L}^{-1}$.
\end{abstract}

Keywords : bittern, coagulant, fish processing waste water

\begin{abstract}
ABSTRAK
Limbah cair proses pencucian pada industri pengolahan ikan mengandung TSS, BOD, COD yang kadarnya melebihi baku mutu, maka dari itu diperlukan pengolahan sebelum dibuang ke badan air. Penelitian ini bertujuan untuk mengetahui efektivitas bittern dalam menurunkan kadar TSS limbah cair. Bittern mengandung magnesium dengan kekuatan ion yang tinggi sehingga dapat dimanfaatkan sebagai koagulan. Penelitian ini diawali dengan mengkondisikan limbah cair agar mempunyai pH 11, kemudian ditambahkan bittern sebanyak 10, 20, 30 dan 40\% dari volume limbah cair yang digunakan. Selanjutnya dilakukan proses jartest, dengan kecepatan pengadukan awal $100 \mathrm{rpm}$ selama 3 menit, dilanjutkan dengan pengadukan lambat $50 \mathrm{rpm}$ selama 15, 30, 45, 60, dan 75 menit. Hasil terbaik diperoleh pada waktu pengadukan 30 menit dengan penambahan koagulan sebesar $40 \%$ dengan hasil akhir TSS 80 mg.L $\mathrm{L}^{-1}$, BOD 48,63 mg.L $\mathrm{L}^{-1}$, COD 93,50 mg.L. ${ }^{-1}$.
\end{abstract}

Kata Kunci : bittern, koagulan, limbah cair pengolahan ikan

\section{PENDAHULUAN}

Salah satu jenis industri yang berkembang saat ini adalah industri pengolahan ikan. Berdasarkan data Kementrian Kelautan dan Perikanan Tahun 2014, produk olahan hasil perikanan dalam kurun waktu pada tahun 2010-2014 meningkat sebesar 6,35\% per tahun, yakni 4,2 juta ton pada tahun 2010 menjadi 5,37 juta ton pada tahun 2014. Peningkatan kapasitas produksi produk pengolahan ikan akan meningkatkan limbah cair yang dihasilkan. Limbah cair ini jika tidak ditangani secara baik akan menimbulkan dampak negatif terhadap lingkungan, karena masih mengandungan zat padat terlarut dan tersuspensi, baik berupa zat organik maupun anorganik sehingga perlu dilakukan penurunan kadar zat padat tersebut, sehingga ketika dibuang ke badan air telah memenuhi baku mutu yang ditetapkan. Penurunan kadar zat padat tersuspensi dapat dilakukan melalui proses koagulasi dan flokulasi dengan menambahkan koagulan. salah satu koagulan alami. salah satu koagulan alami yang dapat dipergunakan adalah Bittern. Bittern merupakan hasil samping dari pembuatan garam rakyat dan selama ini belum dimanfaatkan secara maksimal.

Penelitian ini diharapkan dapat memberikan inovasi dalam pengolahan limbah cair industri khususnya industri pengolahan ikan. Dimana bittern dapat digunakan sebagai koagulan limbah cair industri pada pengolahan ikan serta dapat meningkatkan nilai jual bittern.

\section{TINJAUAN PUSTAKA}

Koagulasi merupakan proses penggumpalan partikel-partikel yang tidak dapat diendapkan langsung secara gravitasi, menjadi partikel yang lebih besar sehingga bisa diendapkan dengan jalan 
menambahkan bahan koagulan. Koagulan adalah bahan kimia yang berfungsi sebagai pengikat partikel-partikel penyebab kekeruhan terhadap air agar terjadi gumpalan atau flok yang mudah diendapkan. Secara umum koagulan berfungsi untuk mengurangi kekeruhan akibat adanya partikel koloid anorganik maupun organik, mengurangi warna yang diakibatkan oleh partikel koloid di dalam air dan mengurangi rasa dan bau yang diakibatkan oleh partikel koloid didalam air.

Flokulasi merupakan suatu proses pengumpalan partikel-partikel terdestabilisasi yang bertumbuhkan agregat sehingga terbentuk flok dengan ukuran yang memungkinkan dapat dipisahkan oleh sedimentasi dan filtrasi. Flokulan berfungsi sebagai pembentuk partikel yang lebih besar (flok). Penambahan flokulan menyebabkan terjadi penetralan muatan kemudian bergabung bersama membentuk flok sehingga akhirnya dapat diendapkan. Pada proses koagulasi diperlukan tahap-tahap proses sebagai berikut, yaitu pertama, pembentukan inti endapan atau bisa disebut pada tahap pengadukan cepat (rapid mix). Pada tahap ini dibutuhkan koagulan, yang fungsinya akan terjadi reaksi penggabungan koagulan dengan zat-zat yang ada dalam limbah cair. Dalam hal ini bittern sebagai bahan koagulan. Koagulan pada tahap ini mutlak diperlukan pengadukan dan pengaturan $\mathrm{pH}$. Pengadukan ini berlangsung pada 60-100 rpm selama 1-3 menit, $\mathrm{pH}$ yang diperlukan bergantung pada jenis koagulan yang digunakan. Dalam hal ini $\mathrm{pH}$ kondisi proses penggunaan bittern adalah 11. Kedua, tahap flokulasi yaitu penggabungan inti-inti endapan menjadi molekul besar (flok). Flokulasi dapat dilakukan dengan pengadukan lambat sekitar 40-50 selama 15-90 menit. Pengadukan yang terlalu cepat dapat merusak flok-flok yang terbentuk dan ketiga merupakan tahap pemisahan flok dari cairan. Flok yang terbentuk selanjutnya dipisahkan dari cairannya, yaitu dengan cara diendapkan atau diapungkan, hingga diperoleh lumpur kimia [1].

Koagulan yang akan dipakai dalam penelitian ini adalah bittern, dimana bittern merupakan hasil samping yang diperoleh dari proses produksi garam rakyat. Bittern sendiri memiliki kandungan mineral seperti Magnesium ( $\mathrm{Mg}$ ), Natrium (Na), Kalsium (Ca), serta garam-garam seperti $\mathrm{CaCl}_{2}, \mathrm{MgCl}_{2}, \mathrm{MgSO}_{4}$, dan $\mathrm{NaCl}$. Bittern dapat dimanfaatkan sebagai koagulan, baik dalam pembuatan tahu dan pada pengolahan limbah cair industri. Bittern dapat digunakan sebagai koagulan pada limbah cair, karena memiliki kanduangan magnesium dengan kekuatan ion sebesar $4,05 \times 10^{-2}$ salinity ${ }^{0,8}[2]$ dan pemanfaatan bittern sebagai koagulan untuk limbah cair industri kertas diperoleh nilai TSS terendah pada penambahan volume bittern $4 \mathrm{ml}$ dengan waktu pengadukan 75 menit. Selain penurunan nilai TSS, \% TSS yang diperoleh juga cukup tinggi yaitu 94,95\% dan $\mathrm{pH}$ akhir limbah cair mengalami juga penurunan dari 11 menjadi 8 [1].

\section{Metode Penelitian}

Penelitian ini diawali dengan menganalisis kandungan TSS, COD dan BOD yang terkandung pada limbah cair, setelah itu dilakukan penambahan bittern pada limbah cair tersebut. adapun prosedur penelitian yang dilakukan ditunjukan pada Gambar 1. 


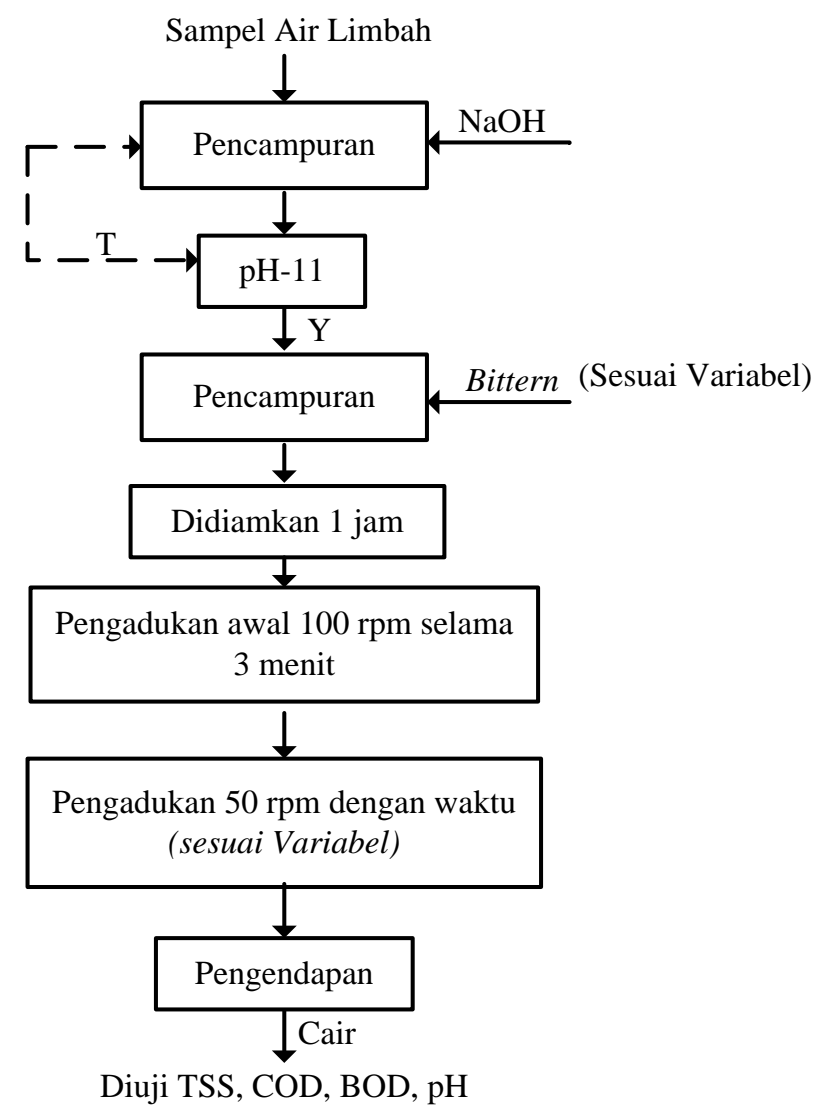

Gambar 1. Skema penelitian

\section{HASIL DAN PEMBAHASAN}

Pada awal penelitian, dilakukan analisis awal untuk mengetahui kondisi dari limbah cair yang digunakan serta menganalisis kandungan Mg pada bittern. Penggunaan bittern dengan kandungan $\mathrm{Mg}$ 8,5\% telah dilakukan [3]. Hasil analisis awal limbah cair pengolahan ikan dapat dilihat pada Tabel 1.

Tabel 1 Hasil Analisis Limbah Cair Pengolahan Ikan

\begin{tabular}{|l|c|c|}
\hline \multirow{2}{*}{ Sampel Awal } & Hasil Analisis Limbah Cair Pengolahan Ikan & \multirow{2}{*}{ Baku Mutu } \\
\hline BOD $\left(\mathrm{mg} . \mathrm{L}^{-1}\right)$ & 204,77 & 100 \\
\hline COD $\left(\mathrm{mg} . \mathrm{L}^{-1}\right)$ & 369,59 & 150 \\
\hline TSS $\left(\mathrm{mg} \cdot \mathrm{L}^{-1}\right)$ & 500 & 30 \\
\hline $\mathrm{pH}$ & 4 & $6,0-9,0$ \\
\hline
\end{tabular}

Berdasarkan Tabel 1 hasil analisis awal limbah cair tersebut melebihi baku mutu Peraturan Gubernur Jawa Timur No. 72 Tahun 2013 sehingga perlu dilakukan pengolahan agar limbah cair tersebut tidak mencemari lingkungan saat dibuang ke badan air [4].

\section{Pengaruh Penambahakan Bittern Terhadap TSS, BOD, dan COD Limbah Cair}

Pengaruh penambahan volume bittern terhadap kadar TSS dengan variabel waktu pengadukan 15, 30, 45, 60, dan 75 menit, dapat dilihat pada Gambar 2. Pada Gambar 2 menunjukkan bahwa terjadi penurunan TSS ketika limbah cair ditambahkan bittern. Kadar TSS pada limbah cair pengolahan ikan mengalami penurunan seiring dengan penambahan volume bittern. Hal ini disebabkan oleh semakin banyak bittern yang ditambahkan maka semakin banyak ion magnesium yang terkandung dalam bittern manarik bahan-bahan organik dan anorganik seperti 
karbohidrat, protein dan lemak sehingga terjadinya destabilitas koloid yang ada pada limbah cair. Ion magnesium ini mempunyai kemampuan mendestabilisasi koloid dengan cara menetralkan muatan listrik pada permukaan koloid yang ada pada limbah cair pengolahan ikan sehingga terbentuk inti gumpalan (inti flok). Selanjutnya inti flok akan ditutupi partikel-partikel koloid yang ada pada limbah cair sehingga membentuk flok dengan ukuran yang lebih besar sehingga mudah mengendap [5].

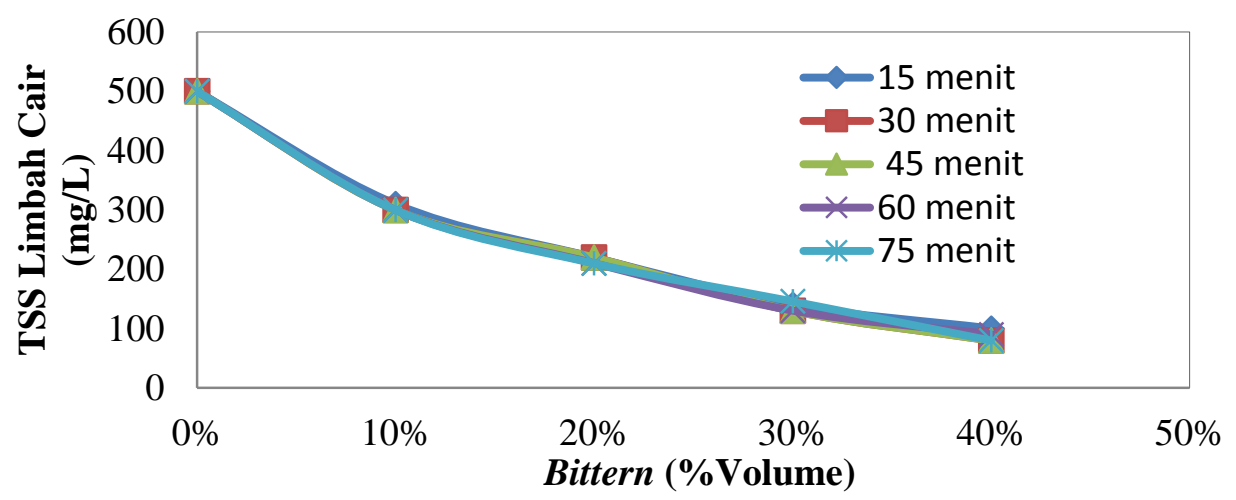

Gambar 2 Pengaruh Volume Bittern Terhadap Kadar TSS Limbah Cair.

Pada penambahan $10 \%$ bittern ke dalam limbah cair pada waktu pengadukan 15 menit mengalami penurunan dari $500 \mathrm{mg} . \mathrm{L}^{-1}$ menjadi $310 \mathrm{mg} . \mathrm{L}^{-1}$, penurunan TSS disebabkan karena ketika bittern ditambahkan disertai pengadukan cepat selama menyebabkan pergerakan partikelpartikel koloid yang ada dalam limbah cair bereaksi dengan bittern secara cepat sehingga jumlah koagulan-flokulan yang ada dalam bittern bereaksi dengan partikel-partikel solid sangat banyak menyebabkan nilai TSS menurun, hal ini juga terjadi pada penambahan bittern sebanyak 20, 30 dan 40\%. Kadar TSS terendah didapatkan dari penambahan $40 \%$ bittern untuk semua variable waktu.

Selain dapat menurunkan TSS, penambahan bittern dapat menurunkan BOD dan COD hal ini dapat dilhat pada Gambar 3 dan Gambar 4

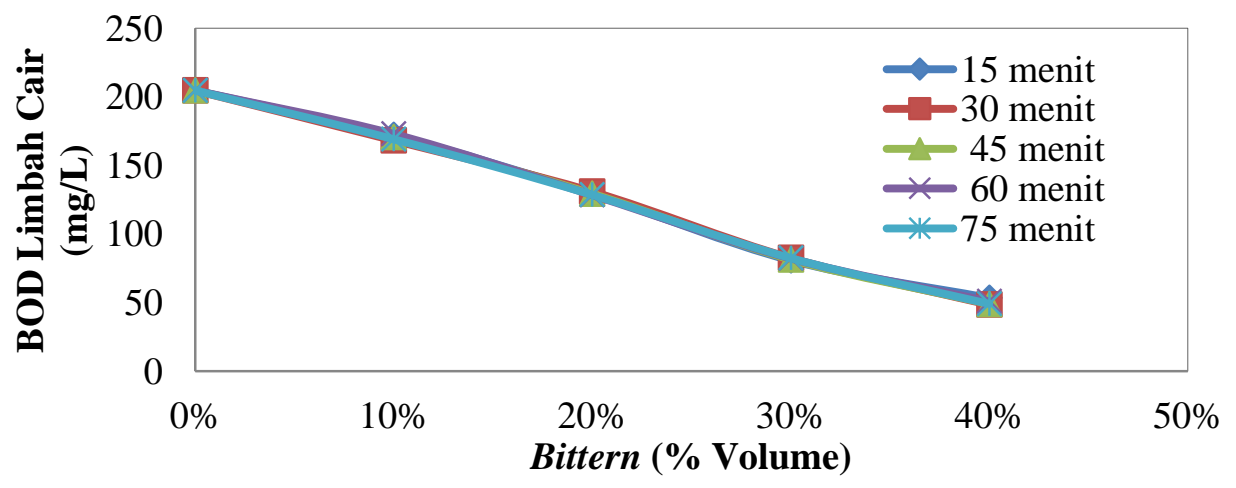

Gambar 3 Pengaruh Volume Bittern Terhadap Kadar BOD Limbah Cair 


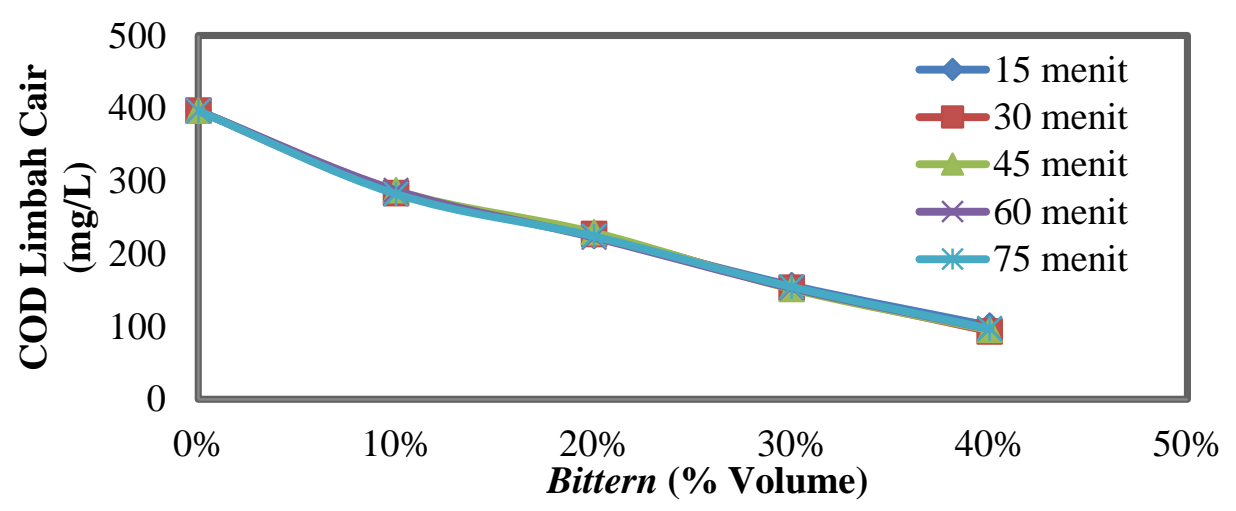

Gambar 4 Pengaruh Waktu Pengadukan terhadap Kadar COD limbah cair.

Pada saat penambahan volume bittern sebanyak 10\% dengan waktu pengadukan 15 menit terjadi penurunan nilai BOD awalnya $204,77 \mathrm{mg} . \mathrm{L}^{-1}$ menjadi $175,25 \mathrm{mg} . \mathrm{L}^{-1}$ atau mengalami penurunan $14,41 \%$ sedangkan penurunan COD awal dari $369,59 \mathrm{mg} / \mathrm{L}$ menjadi $285,20 \mathrm{mg} / \mathrm{L}$ atau mengalami penurunan COD sebesar 22,83\%. Penurunan COD dan BOD ini disebakan karena zatzat organik dan anorganik pada limbah cair pengolahan ikan ikut terdestabilisasi sehingga ikut menggumpal menjadi flok-flok sehingga semakin banyak bittern ditambahkan maka nilai BOD dan COD akan turun. Nilai BOD dan COD terendah didapat dari penambahan $40 \%$ bittern ke dalam limbah cair. Selain dosis penambahan bittern sebagai koagulan, lama pengadukan juga berpengaruh pada nilai akhir TSS, COD dan BOD.

\section{Pengaruh Lama Pengadukan Terhadap TSS, BOD, dan COD Limbah Cair}

Selain dosis penambahan bittern sebagai koagulan, lama pengadukan juga berpengaruh pada nilai akhir TSS, COD dan BOD. Lama pengadukan pada proses koagulasi juga berpengaruh pada penurunan kadar TSS dalam limbah cair. Hal ini ditunjukkan pada Gambar 5.

Pada penambahan volume bittern 10\% dengan lama pengadukan 15 menit menghasilkan $310 \mathrm{mg} . \mathrm{L}^{-1}$, sedangkan pada waktu 75 menit menghasilkan $300 \mathrm{mg} . \mathrm{L}^{-1}$. Secara garis besar dapat dilihat bahwa lama waktu pengadukan menyebabkan penurunan TSS tetapi tidak seterusnya. Pada Gambar 5 menunjukan adanya penyimpangan nilai TSS pada penambahan 30\% dan 40\% volume bittern mengalami kenaikan TSS. Kecenderungan ini terjadi pada variable $40 \%$ volume bittern dengan lama pengadukan 60 menit dan pada variabel 30\% dengan waktu pengadukan 75 menit. Hal ini dapat terjadi karena pada kondisi tertentu, suatu sistem yang telah didestabilisasi dan membentuk agregat dapat menjadi stabil kembali pada agitasi (pengadukan) yang berlebihan dan mengakibatkan adanya flok-flok yang pecah dan larut kembali dalam limbah cair [6]. Hal ini juga mempengaruhi hasil COD dan BOD, hal ini dapat dilihat pada Gambar 6 dan Gambar 7

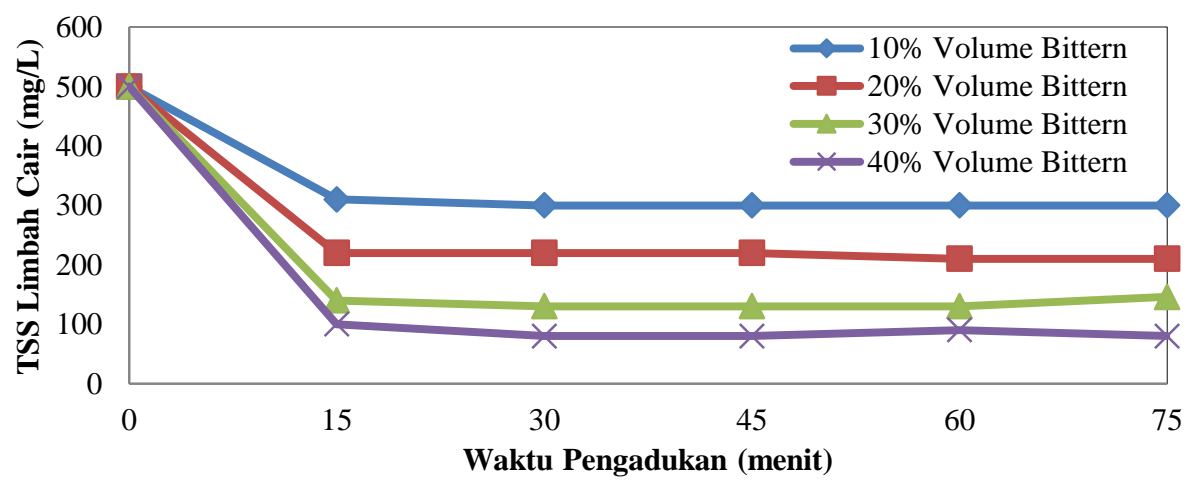

Gambar 5 Pengaruh Waktu Pengadukan Terhadap Kadar TSS Limbah Cair 


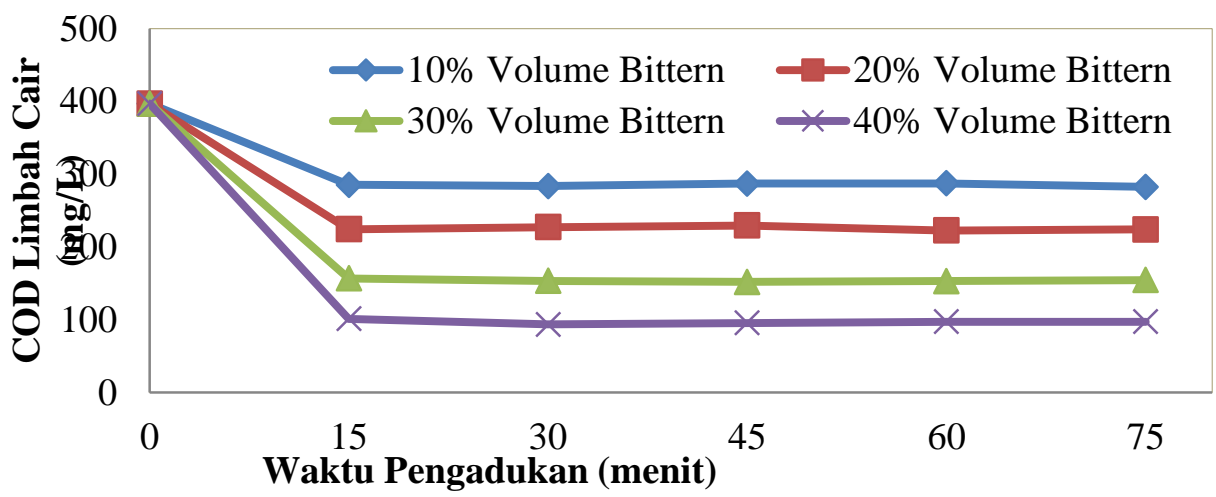

Gambar 6 Pengaruh Waktu Pengadukan terhadap Kadar COD limbah cair.

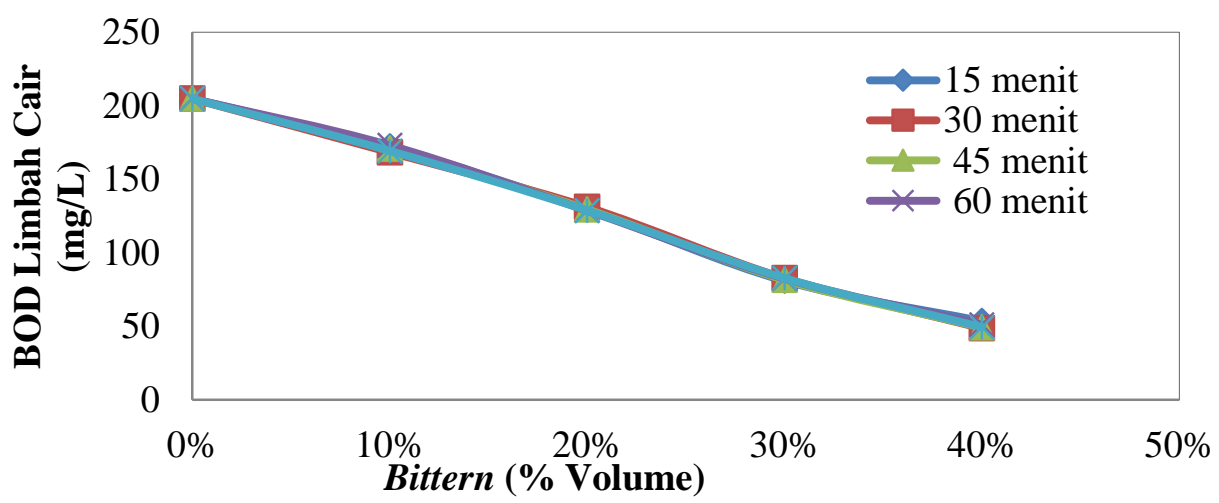

Gambar 7 Pengaruh Volume Bittern Terhadap Kadar BOD Limbah Cair

Pada Gambar 6 dan Gambar 7 menunjukan bahwa pada waktu pengadukan 15 menit dengan penambahan volume bittern $40 \%$ menghasilkan nilai COD sebasar $101,22 \mathrm{mg} . \mathrm{L}^{-1}$ dan nilai BOD sebesar 53,42 mg.. $\mathrm{L}^{-1}$. Pada waktu pengadukan 30 menit dengan penambahan volume bittern $40 \%$ menghasilkan kadar COD sebasar 93,50 mg. $\mathrm{L}^{-1}$ dan nilai BOD sebesar 48,63 mg. $\mathrm{L}^{-1}$. Pada waktu pengadukan 45 menit dengan penambahan volume bittern $40 \%$ menghasilkan COD sebasar 95,49 mg/L dan nilai BOD sebesar 49,16 mg. $\mathrm{L}^{-1}$. Pada lama pengadukan 45 menit nilai COD dan BOD mulai menunjukan peningkatan kembali. Pada waktu pengadukan 60 menit dengan penambahan volume bittern 40\% menghasilkan kadar COD sebasar 97,23 mg. $\mathrm{L}^{-1}$. Pada waktu pengadukan 75 menit dengan penambahan volume bittern $40 \%$ menghasilkan kadar COD sebesar 97,11 mg.L $\mathrm{L}^{-1}$. Pada waktu 15-30 menit, limbah cair mengalami penurunan kadar COD. Penurunan ini disebabkan pada waktu tersebut flok-flok kecil bergabung menjadi lebih besar sehingga mudah mengalami pengendapan. Pada waktu 45-60 menit mengalami kecenderungan kenaikan nilai COD dan BOD. Kenaikan nilai COD dan BOD disebabkan flok-flok yang sudah bergabung terpecah kembali sehingga koloid-koloid yang mengandung bahan organik dan anorganik kembali menjadi stabil [6]. Berdasarkan Gambar 6 dan Gambar 7 dapat diketahui bahwa penambahan $40 \%$ volume bittern dengan lama waktu pengadukan 30 menit kedalam limbah cair, dengan menghasilkan kadar TSS $80 \mathrm{mg} . \mathrm{L}^{-1}$ atau mengalami penurunan $84 \%$, sedangkan kadar COD 93,50 mg. $\mathrm{L}^{-1}$ atau mengalami penurunan 74,70\% dan kadar BOD 48,63 mg. $\mathrm{L}^{-1}$ atau mengalami penurunan $76,25 \%$.

\section{KESIMPULAN}

1. Berdasarkan hasil penelitian dapat disimpulkan bahwa, bittern mampu bekerja secara sebagai koagulan alami

2. Limbah cair pengolahan ikan ketika ditambahkan bittern akan mengalami penurunan kadar TSS, Selain itu penambahan bittern juga mampu menurunkan kadar COD dan BOD.

3. Hasil terbaik pada penelitian ini didapat variabel penambahan $40 \%$ volume bittern dengan lama waktu pengadukan 30 menit kedalam limbah cair, dengan menghasilkan kadar TSS 80 
mg. $\mathrm{L}^{-1}$ atau mengalami penurunan $84 \%$, sedangkan kadar COD 93,50 mg. $\mathrm{L}^{-1}$ atau mengalami penurunan $74,70 \%$ dan kadar BOD 48,63 mg. $\mathrm{L}^{-1}$ atau mengalami penurunan $76,25 \%$.

\section{DAFTAR PUSTAKA}

[1] Sutiyono. 2006. "Pemanfaatan Bittern sebagai Koagulan pada Limbah Cair Industri Kertas". Jurnal Teknik Kimia Vol. 1, No. 1, September 2006.

[2] Wang, S., Chen, K.Y., 1983. "Bitterns as coagulants for the treatment of color Effluents". Proceeding of an International Conference on Chemistry for the Protection of the Environment, Toulouse, France, 19-25 September 1983. pp. 193-203.

[3] Hidayat M, Nur A, 2016. "Pembuatan $\mathrm{MgCl}_{2}$ dari Bittern". Penelitian Jurusan Teknik Kimia, Fakultas Teknologi Industri, ITATS.

[4] Peraturan Gubernur Jawa Timur Nomor 72 Tahun 2013. Baku mutu air limbah untuk industri pengolahan hasil perikanan.

[5] Metcalf \& Eddy, 1991, "Wastewater Engineering Treatment Disposal Reuse”, $2^{\text {nd }}$ edition, McGraw - Hill, Inc., Singapore.

[6] Welasih Tjatoer. 2008. "Penurunan BOD dan COD Limbah Industri Kertas dengan Air Laut sebagai Koagulan". Jurnal Teknik Kimia UPN "VETERAN" Jatim, Vol. 4, No. 2, Februari 2008. 
- Halaman ini sengaja dikosongkan - 